\title{
POESIA INFANTIL: \\ O MAR E SUAS NAUS
}

Marta Morais da Costa*

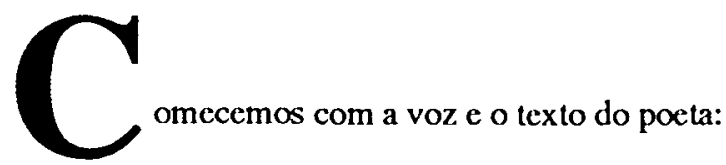

Cada vez que o poeta cria uma borboleta, o leitor exclama: "Olha uma borboleta!". O crítico ajusta os nasóculos e, ante aquele pedaço esvoaçante de vida, murmura: - Ah! sim, um lepidóptero...'

Um texto, três leitores. Aquele que transforma o real em palavra viva o poeta; aquele que identifica, isto é, sente identidade com o texto - o leitor; $\mathrm{e}$ aquele pretenso sábio que mata a vida com rótulos e classificaçōes: o crítico.

Três sujeitos a se expressar, a se definir e a entender a realidade por meio de um poema. Três atitudes que implicam valores diferentes atribuidos a um mesmo produto que, autônomo, continua a existir, inalterado.

Este texto-produto, o poema, alvo de olhares díspares, sempre imperfeitos em sua parcialidade, constitui o suporte, a base, o fundamento do tema deste estudo. Um discurso sobre poesia não existe, porém, no vácuo: sem poemas não há poesia. Mais um exemplo:

* Universidade Federal do Paraná. E-mail: marta (1) coruja.humanas.ufpr.br

${ }^{1}$ QUINTANA, Mário. Sapo amarelo. Hustr. Marco Cena. Porto Alegre: Mercado Aberto, 1984 , p. 38 . 


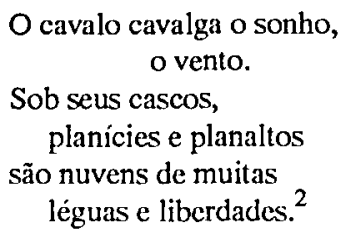

Diria um leitor, à moda do texto de Quintana: "Olha um cavalo!”. A seguir diria outro leitor: "Olha o meu sonho!". Um terceiro: "Viva a liberdade!". Mais um: "Que imagem poderosa do movimento de um animal!". Outro mais: "Como a música das palavras aprecnde o movimento de uma cavalgada!". Enfim: "Sinto-me emocionado pela beleza do conjunto das imagens e da defínição de sonho." E outros, outros, outros...

Este é o lugar da poesia: expressão verbal do poeta, interpretações silenciosas, ou não, mas sempre múltiplas do leitor, espaço $\mathrm{cm}$ que lutam c se multiplicam os sentidos das palavras. Vigência do tempo e da eternidade. Fonte do prazer e da reflexão, a poesia se encaminha diretamente ao pensar-sentir do leitor, depois de sair do refletir e do viver do poeta.

A poesia $\mathrm{em}$ geral $-\mathrm{e}$ a infantil em particular - é múltipla em sua forma, inapreensivel na totalidade de sua significação: momento privilcgiado do despertar de emoções e sensaçōes, instrumento de manipulação no utilitarismo do ambiente escolar, encantamento e magia nas parlendas e cantigas infantis. Diante da pluralidade de interpretações e das múltiplas atitudes dos leitores em relação ao tex to poético, as abordagens das naus piratas do crítico e do professor realizam, por vezes, um saque impiedoso no tesouro poético.

A presente reflexão pretende ser uma modesta abordagem na nau capitanea da poesia para crianças, objetivando resgatar algum butim precioso.

Staiger, ao tratar dos gêneros literários, afirma: “As noções de lírico, épico e dramático são nomes científico-literários aplicados a possibilidades fundamentais da existência humana em geral. ${ }^{3}$ Neste estudo clássico sobre a questão dos gêneros se estabelece como basilar o princípio de união entre o gênero litcrário e a existência humana. De fato, a expressão poética corresponde a uma atitude fundamental do ser humano. Não existe - ou não deveria existir - apenas como uma opção formal. Nesta linha de reflexão, a poesia inicialmente sem destinatário, quer infantil, quer adulto, como toda a literatura - expressa o homem. Este é o mar $\mathrm{cm}$ que navegarei.

${ }^{2}$ CLAVER, Ronald. O jardim dos animais. Ilustr. Ana Raquel. São Paulo: FTD, 1988, p. 21.

${ }^{3}$ STAIGER, Emil. Conceitos fundamentais da poética. Trad. Celeste A. Galeão. Rio de Janeiro: Tempo Brasilciro, 1972, p. 166. 
Acredito ser essencial esta visão humanista da arte, o que me permite buscar - $\mathrm{e}$ por vezes encontrar - no ser humano a fonte $\mathrm{e}$ a foz do rio da arte. Antes, c por trás, de qualquer materialização em palavras, existe um locutor à procura de um interlocutor (receptor) para veicular uma mensagem. $O$ já conhecido circuito da comunicação representa condição indispensável, sem a qual a arte seria impensável. Sabemos, porém, todos nós, que se a poesia se resumisse apenas a um ato de comunicação, uma novela, um filme publicitário, uma canção scrtaneja representariam o néctar e a ambrosia dos deuses poéticos.

Neste momento, recorro a Jakobson: a pexticidade é a equivalência dos vários níveis do discurso articulado. Das scis funçöes da linguagem - a emotiva, a conativa, a metalingüistica, a referencial e a poética - esta última representa a função integradora por excelência. Nela ressoam todas as outras. Privilegiar uma delas equivale a desequilibrar a unidade do texto: é comer o risco de pôr a perder o poético. É na integração que o texto se estrutura, firme e coerentemente. É na percep̧̧ão do caráter íntegro c unitário do texto que se constrói a noção de poesia no leitor.

$\mathrm{Na}$ estcira da reflexão sobre o trânsito entre poeta, poema e leitor é que se pode neste instante refletir a respeito do que se pretende definir como poesia infantil. Uma das mais respeitadas estudiosas do assunto, Maria da Glória Bordini, alerta:

O adjetivo infantil acrescentado à poesia, è central para a discuscão do assunto, de vez que, ao postular esse género literário como arte para um público determinado, os estereotipos referentes a esse público retornam por efeito de ricochete sobre o comportamento da produção pox́tica, podendo privá-la de sua especificidade artistica. ${ }^{4}$

Logo adiante posiciona-se com maior clareza: "a poesia infantil genuína é indistinguivel da poesia não-adjetivada, salvo, talvè, em termos temáticos. ${ }^{5}$

Há um livro clássico contendo estudos sobre a literatura para crianças e jovens intitulado Literatura infanto-juvenil: um gênem polémico ${ }^{6}$. O título define bem o núcleo de uma questão continuamente abordada. A literatura que traz o destinatário infantil ou juvenil incluído $\mathrm{cm}$ seu modo de ser não é polèmica em sua essência (o substantivo literatura), mas em suas restriçēes (os

\footnotetext{
${ }^{4}$ BORDINI, Maria da Glória. Poesia infantil. São Paulo: Ática, 1986, p. 11.

Ibid., p.13.

"KHĖDE, Sonia Salomão. Literatura infanto-juenil: um gènero polemico. Petropolis:
} Vozes, 1983. 
adjetivos infantil e juvenil). Trata-se da sobreposição dos limites, das fronteiras à liberdade estética, que descentra aquelas que seriam as discussões fundamentais para substituí-las por outras, tais como: caracterizar, adequar, subjugar a literatura à faixa etária de seus leitores. Que critérios adotar para a avaliação crítica de textos pré-destinados? Como saber, de antemão, os horizontes de expectativas dos leitores $\mathrm{em}$ formação? Adequar ou liberar? Ir progressivamente superando dificuldades de leitura ou retirar os entraves graduais e permitir saltos e aventuras na formação dos leitores iniciantes?

Estes leitores, e enquanto leitores, são geralmente desassistidos da família e da sociedade em geral. Em conseqüência, só encontrarão objetos de leitura e fruição na instituição escolar, onde se sobrepõem às questões de ordem estético-literárias as intenções pedagógico-utilitaristas.

Não há possibilidade de tratar a poesia infantil sem conhecer as redes de relações que formam ou deformam, preparam ou param o leitor iniciante e ainda imaturo.

Num povo que ama a poesia e que tem uma escola que a odeia, onde situar a poesia infantil? Os pocmas de cordel, as letras de canções, as quadras de adivinhas, os hinos religiosos povoam com rimas, ritmos e imagens os dias e as noites, os ouvidos e os olhos dos brasileiros, sem fichas de leitura, sem análise da versificação, sem a obrigatoriedade de memorizar para a declamação na festa dos pais ou no aniversário do colégio. Esta maré poética se arrebenta, porém, ao encontrar os recifes da instituição escolar. Nela vigoram, segundo as palavras de Maria da Glória Bordini, o "balbucio meloso das emoções ou a voz estrondejante que exalta deveres cívicos ou familiares." Acrescentarei: vigoram também, ao sabor da moda marrom-terra, vulgo ecologia, os animais grandes e pequenos, com vozes onomatopaicas c figurino humano a amolecer de ternura alienante os corações e mentes submissos à vontade e ao gosto adulto. A existência humana é entendida como a vida idealizada de super-heróis sem cuidados nem afazeres, vivendo qual linda borboleta irisada a flutuar no firmamento azul - sem nuvens. As possibilidades fundamentais - pretendidas por Staiger - se transformam em inutilidades sem fundo mental. E a razão de ser da poesia e da vida se achata num racionalismo pragmático - bem ou mal intencionado. Sons, ritmos e imagens se cristalizam no exercicio do hábito de higiene - escovar os dentes, lavar as mãos, tomar banho - e no exercício mnemônico da tabuada, do abecedário, da lição de ciências, dos dias da semana ou dos meses do ano. O progresso do leitor de poesia atinge o ápice quando ele consegue decorar o hino à primavera, o Hino Nacional, um Castro Alves altissonante, um Drummond facilitado c um Manuel Bandeira adocicado -

\footnotetext{
${ }^{7}$ BORDINI, op. cit., p. 8.
} 
isto quando ele chega aos poetas. Freqüentemente não ultrapassa a ode aos pássaros, o passeio dos patinhos ou os cabelos encanecidos da vovozinha que, sempre a ama-seca dos netos, cuida, lava, cozinha e vegeta.

Minha terra perdeu as palmeiras e as cantigas. Em seu lugar, o "Ilariê" e o "Pense em mim" da pobreza musical e letrística; o clogio das abelhas operárias, a exaltação do cstudante, futuro operário da grandiosidade da pátria.

Esclareço: não morto de saudades da escola da "aurora da minha vida" c muito menos da "Criança, não verás nenhum pais como este". Lamento, apenas, as horas perdidas e o cérebro acumulado de chavões, de Brasil varonil e de toda uma galeria de enganos em verso, que podem iludir, distorcer, desvirtuar mas jamais falar de "possibilidades fundamentais da existência humana”. E enquanto se perde tempo com professoras marias e professores antônios que escrevem poemonstros para seus alunos festejarem os pais e o país, dormem nas estantes Drummond, Gabricla Mistral, Fernando Pessoa, Cecília Meireles, Manuel Bandeira, Verlaine, Emily Dickinson, Adélia Prado, Bashô, Orides Fontella e inúmeras estrelas, planctas, sóis, galáxias c... cometas. ${ }^{8}$

Educadores e psicólogos já se cansaram de falar c escrever: a criança reage muito bem ao ritmo, à sonoridade recorrente, ao fantástico. Seu cércbro tem facilidade em trabalhar com a energia da música $\mathrm{c}$ do jogo, indispensáveis à poesia. Por que a poesia - construida por sons, ritmo, musicalidade $e$ imagens - não acompanha c alimenta os sonhos e a formação da sensibilidade c do intelecto do jovem leitor?

A resposta vem rápida, sem rasteiras: o adulto teima em acrescentar aos elementos formadores do poético o utilitarismo da lição de vida, da mensagem, da interpretação única c conclusiva. Não se contenta com o instável, o múltiplo e o lúdico das palavras organizadas em versos e estrofes: necessita dar-lhes uma direção, sempre semântico-ideológica. Para que ler senão para tirar proveito pragmático? Como perder esta ocasião propícia para ensinar valores, comportamentos, regras de vida? A escola, boa aluna da idcologia dominante, esforça-se para obter grau dez, com louvor. Seleciona e fragmenta textos para os livros didáticos - espelhos maléficos de uma noção paternalista c corpóreo-alimentar da escola: o livro é dado como se dão merendas e exercícios de cópia e passividade.

${ }^{8}$ Por várias razōes é digna de elogios a publicação de Poesia fora da estante (Porto Alegre: Projeto, 1996), edição coordenada por Vera Teixeira Aguiar, e Poesia infantil (São Paulo: Instituto Cultural Itaú, 1996), volume coordenado por Luiz Camargo. Nas duas obras é recuperada a possia brasileira escrita contendo a qualidade poética acessivel à sensibilidade da criança ou diretamente pensando nela como destinatária. A respeito dessas duas obras ver resenha neste mesmo número. 
Millôr Fernandes tem toda razão: "Fiquem tranqüilas as autoridades. Entre nós jamais vai haver epidemia de cólera. Nosso povo morre é de passividade."

A literatura é, em princípio e em essência, subversiva, libertadora, estimulante. E o poema é seu caminho mais perfeito, mais refinado - quando poético, evidentemente.

Esta seria uma explicação simplista para nosso desamor à poesia. E, no entanto, perdemos muito em desconhecê-la. Mas conhecer qual poesia infantil? Versos do tipo

\author{
Voz! É o perfeito instrumento \\ Da expressão do pensamento \\ Simples dobras musculares \\ Rústicas, elementares, \\ Duas pregas a vibrar! \\ Formando sons modulados \\ Ressoando articulados \\ Pela passagem do ar! ${ }^{10}$
}

É o escritor tentando deixar desempregado o professor de Ciências. São os sons das palavras subjugados pela avalanche dos conceitos e informações científicos e máxi-retóricos. Sonoridades em pares miseráveis (superlativo para a assim chamada rima pobre) servindo à exaltação do "humano privilégio" de falar. Este ufanismo vocal se serve das palavras como males necessários a serviço de idéias retumbantes e falseadoras. Se falar fosse um privilégio, por que deveríamos continuar assassinando cotidianamente a língua portuguesa?

Este texto em verso sinaliza de forma cabal o uso pedagógico e deturpado do que se denomina poesia. Trata-se de um poema que utiliza os artifícios do verso - rimas, metros, ritmos e imagens - para ornamentar uma lição de anatomia. Por que não usar as palavras para exprimir por elas mesmas e nos seus jogos sintático-semântico-visuais o conceito de fala, como o faz o Fio da fala?

${ }^{9}$ FERNANDES, Millör. Isto É, Rio de Janeiro, n. 1146, p. 9, 11 set. 1991.

${ }^{10}$ AZEVEDO, Maria Alice Penna de. Comersa com o verso: para divertimento e treinamento da fala Ilustr. Neusa M. Batista. São Paulo: Edições Paulinas, 1988, p. 32. 


\begin{tabular}{|c|c|}
\hline $\begin{array}{l}\text { A faca } \\
\text { A faca }\end{array}$ & $\begin{array}{l}\text { corta } \\
\text { fala. }\end{array}$ \\
\hline A faca & fala \\
\hline no seu & FA... \\
\hline A faca & corta \\
\hline no seu & CA... \\
\hline $\begin{array}{l}\text { A faca } \\
\text { quando }\end{array}$ & $\begin{array}{l}\text { fala } \\
\text { corta. }\end{array}$ \\
\hline $\begin{array}{l}\text { A faca } \\
\text { quando }\end{array}$ & $\begin{array}{l}\text { corta } \\
\text { fala. }\end{array}$ \\
\hline $\begin{array}{l}\text { - Você } \\
\text { o fio }\end{array}$ & $\begin{array}{l}\text { afia } \\
\text { da fala? }\end{array}$ \\
\hline $\begin{array}{l}\text { Como a } \\
\text { corta } \\
\text { como o } \\
\text { corta } \\
\text { e o } \\
\text { corta } \\
\text { a fala } \\
\text { corta } \\
\text { pro }\end{array}$ & $\begin{array}{l}\text { nave } \\
\text { o ar } \\
\text { vento } \\
\text { a face } \\
\text { remédio } \\
\text { a dor, } \\
\text { também } \\
\text { caminho } \\
\text { amor!ll }\end{array}$ \\
\hline
\end{tabular}

A faca/fala, par metafórico, no limite da paronomásia, recupera a imagem associada da "faca só lâmina" de Joāo Cabral de Melo Neto, projetando o leitor - não importa se adulto ou criança - para o interior concreto da palavra, enquanto som (fa,ca,la,f,fio,afia,corta,como, etc.) e seus múltiplos parentes sonoros (ve,ce,ar); enquanto visualidade (o fio da faca/ fala corta o poema, segmenta-o e o reúne: $\mathrm{Fa}, \mathrm{Ca}$,faca/fala); enquanto finalidade: a faca corta e ao cortar emite um fio de fala; enquanto metáfora de um mundo mais amplo (a nave, a face, o remédio, a fala e o amor).

De imediato percebemos concretizar-se no jogo poético a sua essência c arte: a palavra como a quer Chico Buarque,

${ }^{11}$ BUSS, Alcides. A poesia do ABC. Ilustr. Leonardo M. B. Gomes. Porto Alegre: Mercado Aberto, 1989. 
Palavra boa

Não de fazer literatura, palavra

Mas de habitar

Fundo

O coração do pensamento, palavra. ${ }^{12}$

Ou como João Cabral: "Flor / é a palavra flor", 13 em “Antiode”.

No oceano abissal da língua, pescar palavras como se fossem pérolas; com clas tecer colares; tecer e destecer; artesanalmente jogar os pentes do tear c no tecido fazer nascer o mundo, como na prosa poética de Marina Colasanti em "A moça tecelā" 14 .

E as crianças? Convidá-las para jogar o jogo das palavras, título do livro de Amélia Lacombe onde fui buscar a idćia irmã do subtítulo deste estudo:

É necessário saltar para dentro do navio da aventura da palavra. E o impulso tem que ser interno, voluntário. Não se faz esta viagem por imposição. Pode-se até embarcar, mas nunca se conhecerá o sabor salgado das ondas... ${ }^{15}$

As imagens redemoinham nos textos de poetas e mestres, a demonstrar que o contato com a poesia contamina e exercita a imaginação e o espírito lúdico. Para que a aventura do jogo-viagem se possa concretizar, torna-se necessário buscar nos textos sua capacidade de expandir-se, de comover, de revelar, de surpreender. Reencontrar não mais o tempo perdido, mas a emoção, a liberdade e a poesia desse tempo.

\author{
Atenção! Compro gavetas, \\ compro armários, \\ cômodas e baús.
}

12 HOLLANDA, Chico Buarque de. "Uma palavra". In: Chico Buarque: letra e música. São Paulo: Companhia das Letras, 1989, v. 1, p. 247.

${ }^{13}$ MELO NETO, João Cabral de. "Antiode". In: __. Antologia poética. 2. ed. Rio de Janeiro: José Olympio, 1973, p. 257.

${ }^{14}$ COLASANTI, Marina. "A moça tecelā". In: Doze reis e a moģa no labirinto do vento. Rio de Janeiro: Nórdica, 1982, p. 12.

${ }^{15}$ LACOMBE, Amélia. O jogo das palavras. São Paulo: Brasiliense, 199 1, p. 22. 
Preciso guardar minhas lembranças, as viagens que não fiz, ciranda, cirandinha e o gosto de aventura que havia nas manhãs.

Preciso guardar meus talismãs o anel que tu me destes, 0 amor que tu me tinhas e as histórias que eu vivi. ${ }^{16}$

O convite para viver a poesia, que é a própria descoberta da poesia, pode ter na criança um surpreendente e redivivo Pedro Álvares Cabral:

\title{
3 de maio
}

Aprendi com meu filho de dez anos Que a poesia é a descoberta

Das coisas que eu nunca vi. ${ }^{17}$

Entrar num universo de sons e sentidos inusitados, de uma nova lógica, $\mathrm{em}$ que caem por terra os intuitos iluministas de ordenar, classificar, definir e estabelecer verdades que se acreditam únicas e eternas. Mundo $\mathrm{em}$ que os sons encadeiam-se em ritmos e em que a significação se descobre enquanto brincadeira, cantiga, dança:

\author{
Uni, duni, tê \\ Salamè minguẽ \\ Um sorvete colorê \\ O escolhido foi você.
}

Poesia que contém música e que, por isso, se faz canção:

${ }^{16}$ MURRAY, Roseana. Classificados poćticos. Ilustr. Paula Saldanha. Belo Horizonte: Miguilim, 1984, p. 6.

${ }_{17}$ ANDRADE, Oswald. Poesias reunidas. 3. ed. Rio de Janciro: Civilização Brasileira, 1972, p. 42. 


\title{
O Pato pateta \\ Pintou o caneco \\ Surrou a galinha \\ Bateu no marreco \\ Caiu no poço \\ Quebrou a tigela \\ Tantas fez o moço \\ Que foi pra panela. ${ }^{18}$
}

Animais que se multiplicam, que se apresentam e representam em formas visuais, dando vida ao desenho das letras, fazendo-as obedecer a um novo traçado igualmente significante, como os poemas figurativos de Antônio Barreto em Isca de pássaro é peixe na gaiola.

Animais que existem pelo som que produzem, concretizando existência e canto:

\author{
SOLFEJO \\ Sai do canto \\ o siriri \\ e quando o sol \\ se levanta \\ ele levanta \\ o seu canto \\ e canta \\ scu dó-ré-mi. \\ Dó-ré-mi \\ fá-sol \\ lá-si \\ si-ri-ri. ${ }^{20}$
}

Mundo que se povoa de bichos-gente e de alegria. Humor que contagia o leitor-gente, impedindo pela descoberta e pela novidade que ele venha a se transformar em gente-bicho:

${ }^{18}$ MORAES, Vinicius de. A arca de Noe. Ilustr. Marie Louise Nery. 21. ed. Rio de Janeiro: Josć Olympio, 1990, p. 47. 1990.

${ }^{19}$ BARRETO, António. Isca de pássaro é peite na gaiola. 2. ed. Bclo Horizonte: Miguilim,

${ }^{20}$ MURALHA, Sidònio. A dança dos picapaus. 3. ed. Rio de Janeiro: Nórdica, 1976, p. 30. 
VIDA DE SAPO

O sapo cai

num buraco

e sai.

Mas noutro buraco

cai.

O sapo cai

num buraco

e sai.

Mas noutro buraco

cai.

É um buraco

a vida do sapo.

A vida do sapo

é um buraco.

Buraco pra cá.

Buraco pra lá.

Tanto buraco enche o sapo. ${ }^{21}$

Quem pode afirmar que a poesia ć a arte do requinte? Na simplicidade e limitação das palavras escolhidas, na construção frasal ordenada e repetitiva, na utilização reiterada do corte do verso, transformando a linha numa seqüência de vazios-buracos, no último verso em paródica chave de ouro com a inusitada troca da consoante final, que imediatamente se associa àquela outra consoante oclusiva da expressão popular, cstabelecendo uma leitura diferente, em que o que se lê não é o lido ou, pelo menos, não é o significado do que se lê com os olhos, são todos recursos que instauram o poético sem recorrer ao retórico ou ao hermético. O sapo do poema é o leitor cansado das armadilhas do pocma tradicional: isto é poesia. E não nasce de emoções ou de graciosas figuras repelentes de batráquios simpáticos - destinados a cativar a criança para a melosa e falsa aceitação do feio - mas o poema é antes de tudo a organização da linguagem que dança e se movimenta ante os olhos do leitor.

${ }^{21}$ PAES, José Paulo. É isso ali: poemas adulto-infanto-juvenis. Ilustr. Carlos Brito. Rio de Janeiro: Salamandra, 1984. 
Poesia que brinca de dizer muito a partir do mínimo e de suas combinaçōes:

\author{
AFINANDO VIOLINO \\ Toco lino \\ viofino \\ toco vio \\ fonolino \\ vio toco \\ linofino \\ toco fino \\ violino $^{22}$
}

O ensaio musical se descreve na estrutura nominal que se embaraça e se refaz, que introduz modulações, variáveis, tons e semitons, arranha e desliza, multiplica-se e unifica-se. As palavras descrevem sem obedecer a habituais fórmulas descritivas. $O$ leitor constrói tex tos como o compositor cria sinfonias a partir de um motivo. Nada de infantilizações pedagógicas e sim convites à aventura das palavras.

Ora direis: poesia que não provoque artepios e não desperte emoçōes não é poesia. Chega de exercícios com a língua! Viva o sentimento! Por exemplo, falar de mãe sempre emociona. Vamos lá:

\title{
AS MÃOS DELA
}

Mãe tem as mãos tão jeitosas

Que fazem coisas gostosas

Para as crianças gulosas!

Mãos que arrumam, que cozinham,

Mãos que lavam, que consertam,

Nessas mãos abençoadas,

Mãos queridas, respeitadas,

Hoje a Terra, carinhosa,

Coloca os botões de rosa

Da universal gratidão.

BENDITA SEJA ESSA MÃO! ${ }^{23}$

${ }^{22}$ CAPARELLI, Sérgio. Tigres no quintal. Ilustr. Gelson Radaelli. Porto Alegre: Kuarup, 1989. p. 57.

${ }^{23}$ AZEVEDO, Conversa com o verso, p. 15. 
Neste discurso tão vasto e tão exagerado não dá para perceber, a não ser pela recorrencia sonora (que por si só não se torna poesia), nenhuma outra atenção com as palavras. Reproduz-se apenas olugar-comum de idéias e formas. Qualquer texto sobre a mãe, apropriado para o Domingo de Maio, usa o mesmo jargão. A única descoberta desse texto é a mesmice.

Ainda prefiro a mãe do Frankstein:

Por ter sido criado em laboratório

Frankstein não teve mãe.

Isso the dava complexo,

especialmente no dia das mães.

Nesse dia, voltou ao laboratório

e pediu uma mãe bionnica.

Quando a viu pronta, ficou tão encantado

e a abraçou com tanto amor

Que a sufocou. Antes de morrer, a mãe

disse ainda, num suspiro:

"Como é doído...

ser mãe...

de Frankstein..." 24

Muito melhor a rima māe-Frankstein do que mãe-mãos, sem dúvida alguma. Apresentados ao leitor iniciante os dois textos, nem Freud explicaria a escolha do primeiro. Já o segundo...

A emoção pode estar presente sem o viés do humor - que distancia toda emoção. Cecília Meireles, ao brincar com as palavras, as silabas e suas cores, ilumina a natureza e o ser que nela vive:

\section{COLAR DE CAROLINA}

Com seu colar de coral

Carolina

corre por entre as colunas

da colina.

${ }^{24}$ PAES, op. cit., [s.p.] 


\section{O calor de Carolina colore o colo de cal, torna corada a menina. \\ E o sol, vendo aquela cor do colar de Carolina põe coroas de coral} nas colunas da colina. ${ }^{25}$

Nem o preço do colar nem o apreço à menina justificam nosso encanto. A emoção nasce do reconhecimento do jogo sonoto, das possibilidades múltiplas de combinação de fonemas, do desafio de enunciação do trava-línguas encoberto - que alguns professores entendem apenas como um exercício de página de cartilha sobre as oclusivas guturais $c a$ e $c o$, e das líquidas $l a, l e, l i, l o, l u$.

Mais do que a mensagem primaveril e colorida da menina a brincar, permanece o encantamento do texto que serpenteia em torno de seus motivos sonoros e imprime no leitor uma força incomum, uma tatuagem.

Entre cores, sons, viagens de barco e aventuras, quero retornar à imagem do ataque pirata à nau da poesia infantil. Saem os poetas, reaparecem os cientistas, por vezes poetas também.

A poesia infantil só merece o adjetivo em sua forma depreciativa infantilóide - quando nela intervém um adulto adulterado, desejoso de mensagens conteudísticas, mordido pelo escorpião do lugar-comum e do diretivismo. O leitor-criança é receptivo ao som, à visualidade, ao humor, à brincadeira, ao prazer, ao descompromisso. Alguns adultos, sem adulteração, assim compreendem este leitor; $\mathrm{c}$ a poesia sem adjetivos pode ser lida e apreciada.

Não importa a fonte: o folclore, a escola, o poeta daqui ou de outras terras, a história, a ciència, o cotidiano, os animais, a música. Poesia infantil não precisa rimar com imbecil. Temos que oferecê-la em bandejas de prata, de aço inoxidável, cm pratos de papelão ou até nas mãos limpas, como alimento básico, como merenda para o espírito, visando a experiência fundamental da existência humana, sem forçar sua aceitação como a de um remédio, lembrando a advertência de Otto Lara Rezende: "Livro não entra na corrida da massificação do lazer. A leitura pede siléncio e solidão. Aliás, sustento que o livro sozinho procura o seu leitor." 26

${ }^{25}$ MEIRELES, Cecília. Ou isto ou aquilo. Ilustr. Beatriz. Berman. Rio de Janeiro: Nova Fronteira, 1990 , p. 9.

${ }^{26}$ REZENDE, Otto Lara. Livro e deslivrização. Folha de São Paulo, São Paulo, p. 2, 23 set. 1991. 
Apresentemos o petisco. Deixemos, porém, o petiz comê-lo prazerosamente com as mãos. Alimento forçado dá engulhos. Talvez que, começando desta maneira, um dia ocorra

\section{O MILAGRE}

Dias maravilhosos em que os jornais vêm cheios de poesia... E do lábio amigo brotam palavras de eterno encanto...

Dias mágicos...

Em que os burgueses espiam,

Através das vidraças dos escritórios,

A graça gratuita das nuvens... ${ }^{27}$

\section{RESUMO}

Este estudo é uma reflexão sobre a poesia infantil enquanto um espaço de linguagem criadora e surpreendente. São oferecidos exemplos tanto de poemas que representam o texto pragmático e formativo quanto, e sobretudo, de poemas em que $o$ poético se revela em imagens, musicalidade, visualidade e humor. A reflexão conclui que a poesia é vital para alimentar o espírito infantil.

Palavras-chave: poesia infantih literatura infantil brasileira, leitura.

\section{RESUME}

Cet étude est une réflexion sur la poésie pour les enfants tandis qu'un espace de langage créatrice et surprenante. Ici se présentent des exemples de poèmes pragmatiques et de formation mais, surtout, des exemples de poèmes où le poétique se révèle en images, musicalité, visualité et humeur. La réflexion concluit que la poésie est vitale pour alimenter l'esprit des enfants.

Palavras-chave: poésie pour enfants, littérature pour enfants au Brésil, lecture.

${ }^{27}$ QUINTANA, Mário. Nova antologia poética. 2. ed. Rio de Janeiro: Codecri, 1981, p. 14. 


\section{REFERÊNCIAS BIBLIOGRÁFICAS}

AGUIAR, Vera Teixeira (org.) Poesia fora da estante. Porto Alegre: Projeto, 1996.

ANDRADE, Oswald de. Poesias reunidas. Rio de Janeiro: Civilização Brasileira, 1972.

AZEVEDO, Maria Alice Penna de. Conversa com o verso: para divertimento e treinamento da fala. Ilustr. Neusa M. Batista. São Paulo: Edições Paulinas, 1988.

BARRETO, Antônio. Isca de pássaro é peixe na gaiola. 2. ed. Belo Horizonte: Miguilim, 1990.

BORDINI, Maria da Glória. Poesia infantil. Sảo Paulo: Ática, 1986.

BUSS, Alcides. A poesia do ABC. Ilustr. Leonardo M. B. Gomes. Porto Alegre: Mercado Aberto, 1989.

CAMARGO, Luis (org.) Poesia infantil. São Paulo: Instituto Cultural Itaú, 1996.

CAPARELLI, Sérgio. Tigres no quintal. Ilustr. Gelson Radaelli. Porto Alegre: Kuarup, 1989.

CLAVER, Ronald. O jardim dos animais. Ilustr. Ana Raquel. São Paulo: FTD, 1988.

COLASANTI, Marina. Doze reis e a moça no labirinto do vento. Rio de Janeiro: Nórdica, 1976.

FERNANDES, Millôr. Isto É, Rio de Janeiro, n. 1146, p. 9, 11 set. 1991.

HOLLANDA, Chico Buarque de. Chico Buarque: letra e música. Sảo Paulo: Companhia das Letras, 1989.

LACOMBE, Amélia. O jogo das palavras: aprendendo português. São Paulo: Brasiliense, 1991.

MEIRELES, Cecilia. Ou isto ou aquilo. Ilustr. Beatriz Berman. Rio de Janeiro: Nova Fronteira, 1990.

MELO NETO, João Cabral de. Antologia poética. Rio de Janeiro: José Olympio/Sabiá, 1973.

MORAES, Vinícius de. A arca de Noé. Ilustr. Marie Louise Nery. 21. ed. Rio de Janeiro: José Olympio, 1990.

MURALHA, Sidônio. A dança dos picapaus. Ilustr. Isabel Pires. Rio de Janeiro: Nórdica, 1976.

MURRAY, Roseana. Classificados poéticos. Ilustr. Paula Saldanha. Belo Horizonte: Miguilim, 1984.

PAES, José Paulo. É isso ali: poemas adulto-infanto-juvenis. Ilustr. Carlos Brito. Rio de Janeiro: Salamandra, 1984.

QUINTANA, Mário. Nova antologia poética. 2. ed. Rio de Janeiro: Codecri, 1981.

QUINTANA, Mário. Sapo amarelo. Ilustr. Marco Cena. Porto Alegre: Mercado Aberto, 1984.

RESENDE, Otto Lara. Livro e deslivrização. Folha de São Paulo, São Paulo, p. 2, 23 set. 1991.

STAIGER, Emil. Conceitos fundamentais da poética. Trad. Celeste A. Galeão. Rio de Janeiro: Tempo Brasileiro, 1972. 